\section{Substance use and sexual risk among at-risk adolescents in Juiz de Fora, Minas Gerais State, Brazil}

\author{
O uso de substâncias e o risco sexual entre \\ adolescentes em situação de risco social \\ em Juiz de Fora, Minas Gerais, Brasil
}

Consumo de sustancias estupefacientes y riesgo
sexual entre adolescentes en situaciones de
riesgo en Juiz de Fora, Minas Gerais, Brasil

\begin{abstract}
${ }^{1}$ Magee-Womens Research
Institute, Pittsburgh, U.S.A.

2 Iowa State University, Ames,

U.S.A.

Correspondence

P. Morrison

Magee-Womens Research

Institute.

3380 Boulevard of the Allies,

Suite 333, Pittsburgh, PA

15213, USA.

morrisonpk@upmc.edu
\end{abstract}

Abstract
We examined the difference in prevalence of substance use and sexual risk behaviors among at-risk youth participants in programs offered by community-based organizations in Juiz de Fora, Minas Gerais State, Brazil, by gender and organization type (governmental vs. non-governmental). 388 adolescents were recruited from 25 intervention-based organizations servicing at-risk youth between the ages of 12 and 17 in Juiz de Fora. Participants completed a 15-item survey assessing substance use and sexual risk behaviors, along with socio-demographic predictors of these behaviors. Males were more likely to report drug and alcohol use associated with homelessness and abandonment. Females were more likely to report sexual risk taking associated with neighborhood crime. Participants from non-governmental organizations were less likely to engage in all measured risk behaviors. The present analysis points to the need to understand how Brazil's Child and Adolescent Act is being applied and the implications this has for intervention and the promotion of positive health outcomes for young people.

Counterfeit Drugs; Sanitary Supervision; Drug and Narcotic Control
Penelope Morrison 1

Amy Erica Smith 2

Aletha Akers ${ }^{1}$

\section{Resumo}

Examinou-se a diferença na prevalência do uso de drogas e comportamento sexual de risco entre os jovens de alto risco em programas oferecidos por organizações localizadas na comunidade de Juiz de Fora, Minas Gerais, Brasil .Foram recrutados 388 adolescentes de 25 organizações de intervenções preventivas que servem jovens de alto risco entre as idades de 12-17. Participantes completaram um questionário com 15 perguntas que avalia o uso de substâncias e o comportamento sexual de alto risco, juntamente com indicadores sociodemográficos. Os adolescentes do sexo masculino foram mais propensos a relacionar o uso de drogas e álcool com a falta de moradia e abandono. As adolescentes do sexo feminino foram mais propensas a reportar comportamentos sexuais de alto risco em associação com o crime comum. Participantes de ONGs foram menos propensos a se envolver nos comportamentos de alto risco pesquisados. A presente análise aponta para a necessidade de se entender as implicações que isso tem para a intervenção preventiva e a promoção de resultados positivos na saúde dos jovens.

Medicamentos Falsificados; Fiscalização Sanitária; Controle de Medicamentos e Entorpecentes 


\section{Introduction}

National surveys of youth risk behaviors, such as the U.S. Youth Risk Behavior Survey and the British Columbia Adolescent Health Survey 1,2, help monitor health risks that contribute to the leading causes of mortality and morbidity among youth, as well as assess the impact of local and national policies. Many emerging countries have no national assessment tools for monitoring of youth risk behaviors. Lingering structural inequalities, coupled with a lack of infrastructure make implementation of systematic instruments difficult 3 . Much of what we know about youth risk taking in parts of the world, including Eastern Europe, Africa and the Caribbean, comes from small, cross-sectional studies that assess single risk behaviors and their relationship to adverse social conditions (e.g. poverty) 4,5,6. Despite the limitations of this approach, these studies provide important insights into the kinds of behavioral health problems youth around the world face. They also contribute to a broader understanding of global adolescent health and well-being.

Brazil is a country where a growing body of research on youth risk behaviors exists. This research demonstrates that young people in conditions of social adversity in Brazil engage in high rates of substance use and sexual risk-taking 7,8,9. While rates of substance use and sexual risktaking vary, previous research has nonetheless shown that substance use (e.g. alcohol, ecstasy or methamphetamines) among at-risk adolescents in Brazil has been linked to exposure to violence, crime, neglect, low-socio-economic status and homelessness 10,11,12. Additionally, adolescents who are exposed to violence at home or in their neighborhood, or who are from low socio-economic backgrounds have also been shown to be more likely to engage in sexual risk taking $12,13,14$. Furthermore, a lack of condom use and other sexual risk behaviors, such as prostitution or exchange sex, have been associated with abandonment and homelessness 11. Finally, youth who engage in substance use are at an increased risk of sexual risk taking behaviors, namely lack of condom use 10,11. Both substance use and sexual risk taking are linked to high rates of sexually transmitted infections, unintended pregnancy, and early death, meaning that a reduction of these health risk behaviors represents an important public health issue 7,15 .

Gender differences in Brazilian youth's engagement in health risk behaviors are also evident. Compared to young women, young men in Brazil are more likely to report initiating drug use at an early age, engaging in heavy episodic drink- ing, being subjected to physical violence, and spending time living and working in the streets 9 , $16,17,18,19$. Young women are more likely to report engaging in sexual risk taking and experiencing abuse or exploitation within the home 14,16,19.

Brazil has made a concerted effort in recent years to improve the health of its youth through social programs that mediate youth risk-taking 20,21. The Child and Adolescent Act (ECA) of 199022 proliferated locally based socio-educative programs as an approach to reducing adolescent engagement in risk behaviors and as a means of diminishing the impact of social risk factors. Today there are many governmental (GO) and nongovernmental organizations (NGOs) in Brazil that specifically target at-risk youth. These entities represent key stakeholders in addressing youth risk behaviors "on the ground". Very little, however, is known about the youth who attend these organizations, how different kinds of social programs may be associated with different types of youth behavior, or to what extent youth in these programs are engaging in substance use and sexual risk taking ${ }^{23}$. These data are important for monitoring trends in youth health risk behaviors, informing the allocation of resources for youth programs and devising future interventions.

\section{Objectives}

In this paper, we examine the overall prevalence of substance use and sexual risk behaviors among youth in programs offered by non-governmental and governmental organizations in Juiz de Fora, as well as differences in such behaviors by gender and organization type. We engaged key stakeholders at GO and NGOs throughout the city to develop a youth risk behavior survey, which was administered within 25 organizations with diverse youth programs. Measures were adapted from existing surveys used in the United States and elsewhere $1,2,10,24$.

\section{Methods}

\section{Sampling}

We conducted a cross-sectional survey in Juiz de Fora, which is located in the southeastern state of Minas Gerais, Brazil and has a population of 520,00025 . Youth from 25 intervention-based organizations servicing at-risk youth were recruited. NGOs and GOs in Juiz de Fora often restrict eligibility for participation in their programs to ages 12-17. Thus, this age range was selected to reflect the population of youth attending participating organizations. In 2008, an estimated 5,200 
youth aged 12-17 were attending local programs for at risk youth in the city of Juiz de Fora 26. It was calculated that approximately 360 youth were needed to reach a confidence level of $95 \%$ and confidence interval of $5 \% 27$.

12 NGOs and 13 GOs were selected for participation. Organizations were eligible based on the following criteria: first, organizations had to specifically work with at-risk youth; second, organizations were randomly selected to represent a range of programs in terms of size (i.e. number of participating youth), organizational structure (non-governmental vs. governmental) and kinds of programs offered, including vocational training, sports, arts, tutoring, and civic courses 26; third, organizations had to serve both boys and girls; and finally, organizations had to be "program based," as opposed to "service based" entities. In other words, they had to maintain a set of regular group-based, instructional activities (e.g., soccer programs or job training) for youth, rather than simply providing access to social assistance or legal or health related services.

Youth were randomly selected at each organization and were eligible if they were between the ages of 12-17, currently enrolled in one of the organization's programs and had a record of regular attendance, defined as visiting the program once a week. Some youth were mandated to participate by the local juvenile council, an entity responsible for dealing with youth in trouble with the law. Others were referred by teachers, parents or social workers, and thus voluntarily recruited.

\section{Survey instrument}

The self-administered, close-ended paper survey contained 15 items assessing four behavioral outcomes of interest (two forms of substance use and two outcomes related to sexual risk behaviors) along with socio-demographic and contextual correlates of these behaviors. The survey took approximately 15 minutes to complete. Data was collected between July and September 2008 by the first author, a Ph.D. trained applied medical anthropologist, and two trained research assistants from local universities. Parental consent was waived and verbal assent from the youth participants obtained in order to ensure adequate recruitment and minimize the potential for negative consequences due to study participation. Many of the youth participants in this study come from unstructured households where parents and/or a legal guardian may be absent or where conditions of abuse, neglect or other adverse situations may have made parental consent impossible, thus limiting enrollment. Similarly, research related to risk often results in insufficient numbers as many youth do not wish for their parents to find out about the behaviors they are engaging in 28; thus, a waiver of parental consent was considered necessary to protect the youths' privacy, and minimize fear of exposure or harm or punishment within the household. The study was approved by the Institutional Review Board at University of Pittsburgh.

Items on the survey instrument were adapted from existing surveys used in other countries. The U.S. Youth Risk Behavior Survey and the British Columbia Adolescent Health Survey are both highly validated, relevant measures for assessing a number of risk behaviors cross culturally, as they have been applied to diverse populations in the USA and Canada. The first author, therefore, reviewed measures from the Youth Risk Behavior Survey 1 and British Columbia Adolescent Health Survey ${ }^{2}$, as well as an instrument developed and tested in Brazil 10,12 in order to identify items that could be translated directly for use in the local context. A list of 25 potential survey items was generated. Each item was reviewed for their relevance to the study population by the first author and a panel of experts from youth services community in Juiz de Fora, including administrative staff, educators, and social workers. Panel members focused on assessing four outcomes related to substance use and sexual risk behaviors, as these were the most common behaviors they encountered, and identified seven potential correlates of adolescent engagement in health risk behaviors for inclusion. Panel members reviewed similar items across the various validated instruments selecting items for inclusion via consensus. All items were translated into Portuguese by a professional translator and reviewed by the panel of experts for language relevance and accessibility for the targeted youth population. Where items could not be translated directly, the panel of experts worked alongside the first author to adapt questions to meet the study needs. Other items were developed anew by the panel where no validated items existed to assess constructs considered essential (e.g. willingness to forgo condoms in the heat of the moment). Additional experts in youth services in Juiz de Fora then reviewed the adapted measures, along with items created by the panel, before pilot testing. For additional insight, we also asked a youth advisory panel to review these measures.

The questionnaire was then pilot-tested for feasibility and clarity among 40 youth in two organizations. During this process, participating youth and organizational staff were asked to provide feedback about each item on the questionnaire in order to assess any difficulties related to language issues, comprehension, or question 
appropriateness respondents might encounter. This information was then presented once more to the panel of experts, who once more tailored to ensure comprehension by the study population. This pilot data was not included in the current study sample.

\section{Health risk behavior outcomes}

Substance use: (1) youth were asked with what frequency they used drugs, exemplified as marijuana, cocaine, aerosol spray cans or other inhalants (glue, paint), heroin, ecstasy, and methamphetamines 1,2,11,29; (2) youth were also asked with what frequency they used alcohol. Response options for each question were, "frequently," "sometimes," "rarely," or "never".

Sexual risk-taking: (1) to assess sexual activity, youth were asked with what frequency they engaged in sex. Response options were "frequently," "sometimes," "rarely," or "never"; (2) condom use is reported only for respondents reporting sexual activity. Participants were asked to respond 'yes' or 'no' to each of these sexual risk-taking items.

\section{Correlates of risk behaviors}

Adolescents were asked to respond yes or no to four separate questions that assessed whether they had ever experienced physical violence, psychological violence, abandonment, and homelessness. In the analysis, abandonment and homelessness are grouped together with a single variable that is coded " 1 " if the respondent had experienced either condition, and "0" otherwise.

In regression models analyzing the factors associated with sexual risk-taking, we also included the other two outcome measures related to substance abuse as much of the literature on at-risk youth shows a strong correlation between these two behaviors 12 .

Socio-demographic measures: neighborhood crime and low neighborhood income have been shown to contribute to risk taking in Brazil 8,10,29. We used an index that measures the amount of neighborhood crime, as reported by youth in response to three questions regarding how common drug trafficking and gangs are, and how safe they feel in the neighborhood. This index was standardized to range from 0 to 1 , where 0 indicates the most secure neighborhoods, and 1 indicates the least secure. Second, we used a measure of neighborhood income which was estimated based on data from the Brazilian national statistics bureau 15. Again, this index has been standardized to run from 0 to 1 , where 0 represents the lowest-income neighborhood in the sample, and 1 represents the highest income neighborhood in the sample. We also examined gender and organizational type (whether NGO or GO) as independent variables (each coded as a binary variable).

\section{Analysis}

We used regression modeling to determine correlates of youth engagement in each of the four health risk behaviors. Drug use, alcohol use and sexual activity were coded on a four-point scale: frequently, sometimes, rarely, or never. These variables were examined using Ordinary Least Squares (OLS). The final variable was coded " 1 " for respondents who said "yes" and "0" for those who said "no" to the following question: "If you're in the heat of the moment ("na hora H" in Portuguese) and you realize you don't have a condom, do you have sex anyway?". We used multivariable logistic regression to model correlates of this final health risk behavior. The multivariate analysis first assesses correlates of the four risk behaviors in the entire sample, that is, for both boys and girls. The sample is then divided between adolescent males and females, and correlates of risk behaviors are assessed in each subgroup. While simple, non-interacted models are presented in the paper, the statistical significance of the differences in findings was also assessed using models in which each of the main independent variables was interacted with the sex of the respondent. The table notes where differences in effects between males and females are statistically significant. All analysis was conducted using Stata v. 11 (Stata Corp., College Station, USA).

\section{Results}

\section{Sample characteristics}

The sample included 388 youth. Data from 14 were excluded due to incomplete survey response. Of the remaining 374 respondents, half (55\%) were female, half self-identified as "pardo" or brown, and a third (34\%) were recruited from NGOs. The overall average age was 15.4 years. Male participants' average age was 15.7 and females' 14.9. All respondents came from $65 \mathrm{mu}-$ nicipally recognized neighborhoods, and the majority (85\% of respondents) from middle to low-income neighborhoods. A third reported exposure to physical violence (30\%), a fifth reported psychological violence (17\%), and 5\% reported abandonment or homelessness. 130 (34\%) youth were surveyed at NGOS and 258 (66\%) were surveyed at governmental organizations. 


\section{Prevalence of health risk behaviors}

The proportion reporting drug use and condom non-use was low at $10 \%$ and $15 \%$, respectively. More than a third reported that they would have sex without a condom in the heat of the moment (39\%). Half reported regular sexual activity (49\%) and alcohol use (42\%). Only $3 \%$ reported having ever had exchange sex.

When stratified by gender, males were more likely to report regular drug use ( $13 \%$ vs. $8 \%, \mathrm{p}<$ 0.05 ) and regular sexual activity ( $58 \%$ vs. $42 \%$, p < $0.05)$ compared to females. No statistically significant gender differences were reported for alcohol use, exchange sex, condom non-use (among the sexually active), or willingness to forgo condoms in the "heat of the moment." Alcohol use was frequently reported by both males (43\%) and females (39\%) while exchange sex was reported rarely by both ( $5 \%$ vs. $2 \%$ )

When stratified by organizational type, risk behaviors are statistically significantly lower among NGO participants for alcohol use (27\% in NGOs vs. $49 \%$ in GO), sexual activity "frequently" or "sometimes" (27\% in NGOs vs. $59 \%$ in GO), and willingness to forgo condoms in the "heat of the moment" (29\% vs. $42 \%$; estimated only for those reporting any sexual activity). A find- ing counter to this pattern is that among those reporting any sexual activity the probability of not using condoms is significantly higher for NGO participants ( $28 \%$ vs. $12 \%$ ). However, only $27 \%$ of NGO participants report ever having had sex ("sometimes" or "frequently"), while $59 \%$ of GO participants report ever having done so. No differences were found between NGO and GO participants in reported rates of exchange sex, abandonment and homelessness, or physical and psychological violence.

\section{Correlates of substance use and sexual risk behaviors among at-risk youth}

Table 1 shows the results of the regression analyses. Since all independent variables are standardized on a $0-1$ scale, coefficients can be interpreted as the effect associated with moving from the sample minimum to the sample maximum on the respective independent variables. As discussed above, the first three columns of coefficients present OLS results for dependent variables that run from 0 to 3 . First we report factors significantly associated with drug use, based on the first column. Drug use was associated with gender. Controlling for other factors, females report levels of drug use that were 0.255 units lower

\begin{tabular}{|c|c|c|c|c|}
\hline & Drugs [B (s.e.)] & Alcohol [B (s.e.)] & Sex $[B(s . e)]$. & $\begin{array}{l}\text { No condoms in the } \\
\text { "heat of the moment" } \\
\text { [B (s.e.)] }\end{array}$ \\
\hline Female & $0.255 *(0.067)$ & $-0.175(0.102)$ & $-0.355 *(0.120)$ & $-0.690 * \star(0.285)$ \\
\hline Drug use & & & $0.275 *(0.101)$ & $0.290(0.207)$ \\
\hline Alcohol use & & & $0.368 *(0.066)$ & 0.592 * $(0.159)$ \\
\hline Neighborhood income & $0.038(0.199)$ & $0.111(0.301)$ & $-0.549(0.344)$ & $-2.365^{\star \star \star}(0.907)$ \\
\hline Neighborhood crime & $0.133(0.142)$ & $-0.158(0.216)$ & $0.679 * \star \star(0.247)$ & $0.979(0.596)$ \\
\hline Physical violence & $0.060(0.077)$ & $0.136(0.116)$ & $-0.116(0.133)$ & $-0.266(0.318)$ \\
\hline Psychological violence & $0.118(0.094)$ & $0.136(0.143)$ & $0.459 *(0.164)$ & $0.860 * *(0.369)$ \\
\hline Abandonment or homelessness & $0.313(0.161)$ & $0.147(0.251)$ & $0.17(0.286)$ & $-0.048(0.647)$ \\
\hline NGO participant & $-0.11(0.070)$ & $-0.561 *(0.106)$ & $-0.657 *(0.126)$ & $-0.787^{* \star}(0.328)$ \\
\hline Constant & $0.272 * \star(0.137)$ & $1.381 *(0.207)$ & $1.065 *(0.251)$ & $-1.046(0.594)$ \\
\hline Number of observations & 360 & 360 & 356 & 354 \\
\hline Adjusted R-squared & 0.044 & 0.072 & 0.277 & \\
\hline Pseudo R-squared & & & & 0.148 \\
\hline
\end{tabular}

s.e.: standard errors.

* Coefficients are statistically significant at $p<0.10$ (two-tailed);

** Coefficients are statistically significant at $p<0.05$ (two-tailed);

$\star \star \star$ Coefficients are statistically significant at $p<0.01$ (two-tailed). 
on the $0-3$ scale than did males. Abandonment or homelessness was also significantly associated with a 0.313 unit increase in drug use on the $0-3$ scale.

Alcohol use, like drug use, was significantly associated with gender, such that females reported levels of alcohol use that were 0.175 units lower than those reported by males. Alcohol use was also strongly and significantly associated with participation in a specific organizational type. NGO participants had alcohol use levels that were 0.561 units lower than GO participants.

Reports of frequency of sexual activity were associated with gender, drug use, alcohol use, neighborhood crime, psychological violence, and organizational participation. Females reported levels of sexual activity that were 0.355 units lower on the 0-3 scale than did males. Those who lived in neighborhoods with the highest crime rates reported levels of sex that were 0.679 units higher than did those living in neighborhoods with the lowest crime rates. In addition, those who had experienced psychological violence engaged in significantly more sex, with levels of sexual activity that were 0.459 units higher on the 0-3 scale. Participants in GO youth programs reported more frequent sexual activity, with program type associated with a 0.657 unit difference. Finally, the most important correlates of sexual activity are drug and alcohol use, the dependent variables from the first two columns of results. Since drug and alcohol use are coded on a $0-3$ scale, rather than a $0-1$ scale, the coefficients must be multiplied by 3 to obtain the effect associated with moving from the minimum to the maximum on each independent variable. Those who report they use drugs "frequently" have levels of sexual activity that are 0.825 units higher on the 0-3 scale than do those who report they "never" use drugs. In addition, those who report they use alcohol "frequently" have levels of sexual activity that are 1.104 units higher than those who "never" use alcohol.

Willingness to forgo condom use in the "heat of the moment" was associated with gender, alcohol use, neighborhood income, psychological violence, and organizational participation. The predicted probability of agreement with the statement among females is 0.197 , and among males it is 0.328 (all probabilities are calculated holding dichotomous control variables at their minimums and continuous and ordered control variables at their means). At the highest level of alcohol use, the probability of willingness to forgo condom use in the "heat of the moment" is 0.598 , while at the lowest level of alcohol use the probability is 0.201 . Residents of the lowestincome neighborhoods had a probability of agreeing with the statement of 0.561 , while those in the highest income neighborhood had a probability of only 0.107 . Victimization by psychological violence raises the probability of agreement from 0.328 to 0.536 , and GO participation raises the probability of being willing to forgo condoms from 0.182 to 0.328 .

Risk factors as determinants of substance use and sexual risk behaviors by gender

A gender-stratified analysis examining correlates of engagement in each health risk-behavior is shown in Table 2. The first two columns of coefficients examine risk factors associated with drug use among males and females, respectively. Among males, drug use is associated with abandonment or homelessness, while they are unassociated among females. That is, males who have experienced abandonment or homelessness report higher levels of drug use. As represented by the bold coefficients and standard errors, analysis of the gender interaction indicates that the difference between males and females in the association between abandonment/homelessness and drug use is statistically significant.

The third and fourth columns of coefficients examine risk factors associated with alcohol use among females and males. Among females, alcohol use is negatively correlated with NGO participation and positively correlated with physical violence. Among males, by contrast, alcohol use is positively associated with psychological violence and abandonment or homelessness, while it is negatively associated with NGO participation. That is, males who have been victims of psychological violence or abandonment and homelessness report more alcohol consumption. Both males and females in GOs report greater alcohol use. Analysis of the gender interaction indicates that the difference between males and females is statistically significant only for the effects of psychological violence and abandonment or homelessness.

The fifth and sixth columns of coefficients present correlates of frequency of sexual activity among males and females, respectively. In those columns we find that among females, sexual activity is positively correlated with alcohol use, neighborhood crime, and psychological violence, and negatively correlated with NGO participation. Meanwhile, among males sexual activity is positively associated with drug and alcohol use, while it is negatively associated with neighborhood income and NGO participation. Thus, both females and males who drink alcohol more frequently and who participate in GOs report more frequent sexual activity. Females who 
Table 2

Risk factors as determinants of substance use and sexual risk behaviors by gender, among at-risk youth participating in social programs in Juiz de Fora, Minas Gerais State, Brazil.

\begin{tabular}{|c|c|c|c|c|c|c|c|c|}
\hline & \multicolumn{2}{|c|}{ Drugs } & \multicolumn{2}{|c|}{ Alcohol } & \multicolumn{2}{|c|}{ Sex } & \multicolumn{2}{|c|}{$\begin{array}{l}\text { No contraceptives in the } \\
\text { "heat of the moment" }\end{array}$} \\
\hline & Girls & Boys & Girls & Boys & Girls & Boys & Girls & Boys \\
\hline Drug use & & & & & $0.245(0.179)$ & $\begin{array}{l}0.332 \text { * } \\
(0.124)\end{array}$ & $0.238(0.370)$ & $\begin{array}{l}0.480 * \star \\
(0.275)\end{array}$ \\
\hline Alcohol use & & & & & $\begin{array}{l}0.400 * \\
(0.090)\end{array}$ & $\begin{array}{l}0.321 * \\
(0.100)\end{array}$ & $\begin{array}{l}0.817 * \\
(0.240)\end{array}$ & $\begin{array}{l}0.431 * \star \star \\
(0.231)\end{array}$ \\
\hline Neighborhood income & $\begin{array}{l}0.017 \\
(0.213)\end{array}$ & $\begin{array}{c}0.093 \\
(0.363)\end{array}$ & $\begin{array}{l}-0.021 \\
(0.401)\end{array}$ & $\begin{array}{c}0.299 \\
(0.451)\end{array}$ & $\begin{array}{c}0.117 \\
(0.490)\end{array}$ & $\begin{array}{l}-1.356 * \\
(0.474)\end{array}$ & $\begin{array}{l}-2.212 \\
(1.357)\end{array}$ & $\begin{array}{c}-2.786 * \star \star \\
(1.280)\end{array}$ \\
\hline Neighborhood crime & $\begin{array}{c}0.055 \\
(0.149)\end{array}$ & $\begin{array}{c}0.254 \\
(0.268)\end{array}$ & $\begin{array}{l}-0.087 \\
(0.282)\end{array}$ & $\begin{array}{l}-0.226 \\
(0.332)\end{array}$ & $\begin{array}{l}1.109 * \\
(0.346)\end{array}$ & $\begin{array}{c}0.019 \\
(0.353)\end{array}$ & $\begin{array}{l}1.921 * \star * \\
(0.907)\end{array}$ & $\begin{array}{l}-0.090 \\
(0.842)\end{array}$ \\
\hline Physical violence & $\begin{array}{l}0.142 * \\
(0.086)\end{array}$ & $\begin{array}{c}0.005 \\
(0.135)\end{array}$ & $\begin{array}{l}0.280 * \\
(0.162)\end{array}$ & $\begin{array}{c}0.063 \\
(0.168)\end{array}$ & $\begin{array}{l}-0.209 \\
(0.201)\end{array}$ & $\begin{array}{l}-0.022 \\
(0.177)\end{array}$ & $\begin{array}{l}-0.263 \\
(0.509)\end{array}$ & $\begin{array}{l}-0.417 \\
(0.429)\end{array}$ \\
\hline Psychological violence & $\begin{array}{c}0.07 \\
(0.092)\end{array}$ & $\begin{array}{c}0.166 \\
(0.199)\end{array}$ & $\begin{array}{l}-0.092 \\
(0.174)\end{array}$ & $\begin{array}{c}0.519 * * * \\
(0.248)\end{array}$ & $\begin{array}{c}0.499 * \star \star \\
(0.214)\end{array}$ & $\begin{array}{c}0.445 * \star \\
(0.264)\end{array}$ & $\begin{array}{c}0.924 \text { ** } \\
(0.506)\end{array}$ & $\begin{array}{c}0.905 \\
(0.595)\end{array}$ \\
\hline Abandonment or homelessness & $\begin{array}{c}0.191 \\
(0.137)\end{array}$ & $\begin{array}{c}1.185 * \star \star \\
(0.560)\end{array}$ & $\begin{array}{l}-0.042 \\
(0.267)\end{array}$ & $\begin{array}{c}1.629 \star * \star \\
(0.696)\end{array}$ & $\begin{array}{c}0.130 \\
(0.326)\end{array}$ & $\begin{array}{c}0.119 \\
(0.747)\end{array}$ & $\begin{array}{c}0.493 \\
(0.710)\end{array}$ & \\
\hline NGO participant & $\begin{array}{l}-0.067 \\
(0.074)\end{array}$ & $\begin{array}{l}-0.215 \\
(0.133)\end{array}$ & $\begin{array}{l}-0.533 \text { * } \\
(0.140)\end{array}$ & $\begin{array}{l}-0.635 \text { * } \\
(0.164)\end{array}$ & $\begin{array}{l}-0.787 \text { * } \\
(0.177)\end{array}$ & $\begin{array}{c}-0.428 \text { *** } \\
(0.182)\end{array}$ & $\begin{array}{c}-1.430 * \star \star \\
(0.593)\end{array}$ & $\begin{array}{l}-0.149 \\
(0.433)\end{array}$ \\
\hline Constant & $\begin{array}{c}0.055 \\
(0.141)\end{array}$ & $\begin{array}{c}0.221 \\
(0.244)\end{array}$ & $\begin{array}{l}1.234 \text { * } \\
(0.265)\end{array}$ & $\begin{array}{l}1.331 \text { * } \\
(0.303)\end{array}$ & $\begin{array}{c}0.216 \\
(0.341)\end{array}$ & $\begin{array}{l}1.688 \text { * } \\
(0.341)\end{array}$ & $\begin{array}{l}-2.663 \text { * } \\
(0.892)\end{array}$ & $\begin{array}{l}-0.237 \\
(0.827)\end{array}$ \\
\hline Observations & 207 & 153 & 205 & 155 & 203 & 153 & 202 & 150 \\
\hline Adjusted R-squared & 0.020 & 0.015 & 0.049 & 0.128 & 0.256 & 0.286 & & \\
\hline Pseudo R-squared & & & & & & & 0.199 & 0.125 \\
\hline
\end{tabular}

Note: standard errors in parentheses.

* Coefficients are statistically significant at $p<0.01$ (two-tailed);

** Coefficients are statistically significant at $p<0.10$ (two-tailed);

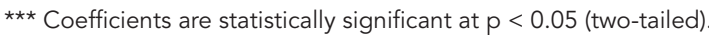

Coefficients in bold are ones for which the difference between males and females is statistically significant at $p<0.10$. Models of drug and alcohol use and sexual activity are estimated using ordinary least squares (OLS). The model of no contraceptive use "in the heat of the moment" is estimated using logistic regression. The indicator of homelessness is omitted from the final model because homelessness is a perfect negative predictor of this risk behavior among males.

have been victims of psychological violence and live in high crime neighborhoods also have more frequent sexual activity, while males who report more frequent drug use and who live in lower income neighborhoods report having sex more often. The difference in coefficients between males and females is statistically significant for neighborhood income and neighborhood crime. That is, males are more sensitive to neighborhood income, while females are more sensitive to neighborhood crime.

Finally, the remaining columns examine the risk factors associated with a willingness to forgo condoms "in the heat of the moment". Among females, this behavior is positively associated with neighborhood crime and psychological violence, and negatively associated with NGO participation. Among males, it is negatively associated with neighborhood income. That is, females who live in higher crime neighborhoods, and who participate in GOs (as opposed to NGOs) are all more likely to engage in this behavior. By contrast, this behavior is more likely in males who live in lower income neighborhoods. In addition, as with general sexual activity, alcohol use boosts willingness to forgo contraception for both sexes, while drug use does so only among males. The difference in coefficients between males and females is statistically significant only for neighborhood crime. 


\section{Discussion}

The goal of the present analyses was to examine the prevalence of substance use and sexual risk behaviors among youth engaged in programs offered by NGOs and GOs overall, as well as differences in risk behaviors by gender and organizational type. Our findings support the extant literature on socially vulnerable youth populations and risk behaviors from Brazil and elsewhere, and suggest that efforts to address the individual needs of males and females are warranted 9,16,17,18 .

Over half of all participants reported frequent alcohol use, however, no statistically significant differences were found between males and females. Additionally, sexual activity was positively correlated with alcohol use for both males and females. This finding is not surprising given that literature from the USA, South Africa and Brazil have found similar associations between alcohol use and engagement in sexual activity among socially vulnerable populations of youth 8,30,31,32 . Similarly, in Brazil studies have shown a correlation between alcohol use and sexual risk taking among both young men and women, leading to issues such as unplanned pregnancies and sexually transmitted infections (STIs) 32 . Our study supports these findings and suggests that perhaps more focused education is needed for atrisk youth in Brazil around the area of alcohol use and safe sex practices.

We found that males are more likely to engage overall in sexual activity and drug use than females. Thus, our study supports some of the literature from Brazil that reports higher rates of alcohol and drug use among young men in general $16,17,18$. We also found that homelessness and abandonment increased the likelihood that males will engage in drug and alcohol use. Studies from other parts of Latin America and India have shown that a lack of family connectedness is often associated with an increased engagement in risk behaviors, including drug and alcohol use, particularly for young men 33,34,35. In Brazil, de Carvalho et al. 11 showed that boys who spend more time living or working in the street exhibit lower levels of family connectedness than their female counterparts, but also engage more in substance abuse. Furthermore, though drug use here is relatively low, our data nonetheless support studies from Brazil showing that boys, particularly those in conditions of social adversity, are generally more likely to engage in substance abuse than girls 17 . This work, therefore, suggests that targeted efforts to reduced substance abuse among boys are needed in Brazil.

Among females, we found that sexual activity was also associated with psychological violence and neighborhood crime, and a willingness to forgo condoms in the heat of the moment was also associated with neighborhood crime. It is unclear why psychological violence and neighborhood crime might have this affect; two reasons can be postulated: first, young women living in tenuous settings in Brazil may couple with partners out of fear or for protection; second, such pairings together with lingering traditional gender roles in Brazil may make condom negotiation difficult for women. Indeed, evidence from Brazil and elsewhere suggests that gender power dynamics can impact upon the ability of young women, particularly those living in conditions of socio-economic disparity, to negotiate and advocate for condom use in their relationships 36,37. Nonetheless, considering that adolescent females aged 15 to 19 are responsible for almost $20 \%$ of all new births in Brazil, this study suggest that perhaps more contraceptive education overall is needed for youth, and that specific education regarding condom negotiation skills is needed for young women 38 .

Finally, our study also found differences in youth risk behaviors across organization types. NGO participants were less likely to engage in all risk behaviors, although NGOs reduce willingness to forgo condom use only among girls. Though the impact of organization type on risk behaviors is unclear, several possible explanations can be given. NGOs tend to be community based and limited in their outreach capacity. They therefore may have larger proportions of youth in their programs that are simply not engaging in risk behaviors. Relatedly, NGOs serve a smaller number of participants, which may facilitate their capacity to offer more tailored programs (e.g. condom use efficacy among females). Nonetheless, in the absence of national measures, this present analysis serves as a baseline from which to suggest ways that both governmental and non-governmental organizations can improve their outreach by working to tailor their services to better meet the unique demands of the populations they serve.

\section{Limitations}

Due to the relatively small sample size, statistical power was somewhat limited. This may have contributed to the lack of statistical significance of some hypothesized risk factors. Furthermore, our sample only includes at-risk youth who are involved in organizational programming; thus, it is unclear if it is representative of other subsets of adolescent populations or youth in general in Brazil. Additionally, characteristics of youth 
might differ depending on how they were recruited into organizations (social services vs. voluntary). However, as participating organizations recruit youth known to engage in risk behaviors and others who need alternative opportunities for development, we argue that our sample was fairly representative of a broad range of youth in the city of Juiz de Fora.

Differences between males and females must also be interpreted with caution given the number of pairwise comparisons being performed. At a $95 \%$ confidence level, one can expect $5 \%$ of statistical tests to yield a Type I error, falsely rejecting the null hypothesis. With 28 paired comparisons between males and females, this would mean that at least one comparison would appear to be statistically significant by chance. In fact, out of 28 comparisons, six were found to be statistically significant. In this case, we prefer to report all comparisons uncorrected, while acknowledging the challenges in assessing statistical significance.

The cross-sectional nature of our data is also a limitation. While our data do not reveal how programs affect participants' risk behaviors and factors over time, this research is nonetheless an important first step to prepare the empirical and conceptual groundwork for future longitudinal research in this area. Such data is needed as baseline to begin to address the efficacy of these programs for mediating risk behaviors of Brazilian youth.
Finally, while the measures were developed in close consultation with local service providers and youth and were pretested, their reliability and validity needs further investigation. All data are based on self-report on a survey implemented in the participating organizations, and the bias relative to external measures of risk behaviors is not known for this population. It is also unclear what effect the programs utilized in this study may have had on the variables investigated. Survey replication in other areas, as well as longitudinal investigations of youth in such programs, are needed to address some of these issues.

\section{Conclusion}

The present analysis, which explores the prevalence of substance abuse and sexual risk and associated risk factors among adolescents attending youth programs in Brazil, expands our understanding of how young Brazilian men and women experience risk differently and the factors that may contribute to risk taking. While the present analysis can only suggest associations, it is nonetheless consistent with data emerging from Brazil. Namely, this work supports research from Brazil that demonstrates higher rates of substance use among boys and sexual risk taking among girls in socially vulnerable situations. Additionally, our findings support research that shows a relationship between alcohol use and sexual risk taking among these risk adolescents. 


\section{Resumen}

Examinamos las diferencias en la prevalencia de uso de sustancias estupefacientes y el riesgo sexual entre los jóvenes participantes de los programas ofrecidos por las organizaciones de base comunitaria en Juiz de Fora, Minas Gerais, Brasil. Se incorporaron 388 adolescentes de 25 organizaciones de apoyo e intervención a la juventud, que atienden a chicos de entre de 12-17 años en Juiz de Fora. Los participantes completaron un estudio con 15-ítems para evaluar el consumo de sustancias estupefacientes y el riesgo sexual, junto a aspectos sociodemográficos predictores de estos comportamientos. Los varones tenían más probabilidades de uso de drogas y alcohol, asociado al desamparo y abandono. Las mujeres tenían más probabilidades de riesgos sexuales, relacionados con la delincuencia del barrio. Los participantes de las organizaciones no gubernamentales tenían menos probabilidades de comportamientos de riesgo. El presente análisis apunta la necesidad de entender cómo se está aplicando la ley del niño y del adolescente y las consecuencias que tiene para la intervención y la promoción de los resultados positivos para la salud.

Medicamentos Falsificados; Fiscalización Sanitaria; Control de Medicamentos y Narcóticos

\section{References}

1. Eaton DK, Kann L, Kinchen S, Shanklin S, Ross J, Hawkins J, et al. Youth risk behavior surveillanceUnited States, 2009. MMWR Surveill Summ 2010; 59:1-142.

2. Smith A, Stewart D, Peled M, Poon C, Saewyc E. A picture of health: highlights from the $2008 \mathrm{BC}$ adolescent health survey. Vancouver: McCreary Centre Society; 2009.

3. Fatusi AO, Hindin MJ. Adolescents and youth in developing countries: health and development issues in context. J Adolesc 2010; 33:499-508.

4. Calazans G, Araujo TW, Venturi G, França IJ. Factors associated with condom use among youth aged 15-24 years in Brazil in 2003. AIDS 2005; 19 Suppl 4:S42-50.

5. Kissin DM, Zapata L, Yorick R, Vinogradova EN, Volkova GV, Cherkassova E, et al. HIV seroprevalence in street youth, St Petersburg, Russia. AIDS 2007; 21:2333-40.

\section{Contributors}

P. Morrison contributed to the study design, paper proposal, data collection, data analysis and manuscript preparation. A. E. Smith contributed to the data collection, data analysis and manuscript preparation. A. Akers contributed to the data analysis and manuscript preparation.
6. Magnani RJ, Karim AM, Weiss LA, Bond KC, Lemba M, Morgan GT. Reproductive health risk and protective factors among youth in Lusaka, Zambia. J Adolesc Health 2002; 30:76-86.

7. Carlini-Cotrim B, Gazal-Carvalho C, Gouveia N. Comportamentos de saúde entre jovens estudantes das redes pública e privada da área metropolitana do Estado de São Paulo. Rev Saúde Pública 2000; 34:636-45.

8. Cardoso AR, Verner D. Youth risk-taking behavior in Brazil: drug use and teenage pregnancy. Washington DC: World Bank; 2008.

9. Vieira PC, Aerts DRGC, Freddo SL, Bittencourt A, Monteiro L. Uso de álcool, tabaco e outras drogas por adolescentes escolares em município do Sul do Brasil. Cad Saúde Pública 2008; 24:2487-98.

10. Anteghini M, Fonseca H, Ireland M, Blum RW. Health risk behaviors and associated risk and protective factors among Brazilian adolescents in Santos, Brazil. J Adolesc Health 2001; 28:295-302. 
11. de Carvalho FT, Neiva-Silva L, Ramos MC, Evans J, Koller SH, Piccinini CA, et al. Sexual and drug use risk behaviors among children and youth in street circumstances in Porto Alegre, Brazil. AIDS Behav 2006; 10(4 Suppl):S57-66.

12. Verner D, Alda E. Youth at risk, social exclusion, and intergenerational poverty dynamics: a new survey instrument with application to Brazil. Washington DC: World Bank; 2004.

13. Peres CA, Rutherford G, Borges G, Galano E, Hudes ES, Hearst N. Family structure and adolescent sexual behavior in a poor area of Sao Paulo, Brazil. J Adolesc Health 2008; 42:177-83.

14. Teixeira SAM, Taquette SR. Violence and unsafe sexual practices in adolescents under 15 years of age. Rev Assoc Med Bras 2010; 56:440-6.

15. Instituto Brasileiro de Geografia e Estatística. Síntese de indicadores sociais: uma análise das condições de vida da população brasileira. Rio de Janeiro: Instituto Brasileiro de Geografia e Estatística; 2009.

16. de Farias JC Jr., Nahas MV, de Barros MV, Loch MR, de Oliveira ES, De Bem MF, et al. Comportamentos de risco é saúde em adolescentes no Sul do Brasil: prevalência e fatores associados. Rev Panam Salud Pública 2009; 25:344-52.

17. Carlini-Marlatt B, Gazal-Carvalho C, Gouveia N, de Fátima Marinho Souza M. Drinking practices and other health-related behaviors among adolescents of São Paulo City, Brazil. Subst Use Misuse 2003; 38:905-32.

18. Raffaelli M, Koller SH, Reppold CT, Kuschick MB, Krum FM, Bandeira DR, et al. Gender differences in Brazilian street youth's family circumstances and experiences on the street. Child Abuse Negl 2000; 24:1431-41.

19. Martins CBG, Jorge MHPM. Abuso sexual na infância e adolescência: perfil das vítimas e agressores em município do sul do Brasil. Texto \& Contexto Enferm 2010; 19:246-55.

20. Rizzini I. The promise of citizenship for Brazilian children: what has changed? Ann Am Acad Pol Soc Sci 2011; 633:66-79.

21. de Almeida Dias SL, Sieben M, Cozer P, Borghetti Alves R, Haubert T. Estatuto da Criança e do Adolescente: aprendendo cidadania. Inclusão Social 2007; 2:116-23.

22. Brasil. Lei no 8.069, de 13 de Julho de 1990. Dispõe sobre o Estatuto da Criança e do Adolescente, e dá outras providências. Diário Oficial da União 1990; 16 jul.

23. Morrison PK, Nikolajski C, Borrero S, Zickmund S. Youth perspectives on risk and resliency: a case study from Juiz de Fora, Brazil. Youth \& Society 2012; XX:1-24. http://yas.sagepub.com/con tent/early/2012/04/01/0044118X12441614.full. pdf + html.

24. Noto AR. Levantamento nacional sobre o uso de drogas entre crianças e adolescentes em situação de rua nas 27 capitais brasileiras, 2003. São Paulo: Centro Brasileiro de Informações sobre Drogas Psicotrópicas, Departamento de Psicobiologia, Escola Paulista de Medicina, Universidade Federal de São Paulo; 2004
25. Universidade Federal de Juiz de Fora. Anuario estatistico 2009. http://www.cps.ufjf.br/anuarios/ Anuario2010/index.html. (accessed on 15/Apr/ 2012).

26. Associação Municipal de Apoio Comunitário. Projecto Novo Cidadão: guia de instituições e serviços de atendimento à criança e ao adolescente de Juiz de Fora. Juiz de Fora: Prefeitura de Juiz de Fora; 2008.

27. Bartlett JE, Kotrlik JW, Higgins CC. Organizational research: determining apropriate sample size in survey research. Informational Technology, Learning and Performance Journal 20001; 19:43-50.

28. Wagener DK, Sporer AK, Simmerling M, Flome JL, An C, Curry SJ. Human participants challenges in youth-focused research: perspectives and practices of IRB administrators. Ethics Behav 2004; 14:335-49.

29. Kokkevi A, Richardson C, Florescu S, Kuzman M, Stergar E. Psychosocial correlates of substance use in adolescence: a cross-national study in six European countries. Drug Alcohol Depend 2007; 86: 67-74.

30. Morojele NK, Brook JS, Millicent A, Kachieng A. Perceptions of sexual risk behaviours and substance abuse among adolescents in South Africa: a qualitative investigation. AIDS Care 2006; 18 : 215-9.

31. Tapert SF, Aarons GA, Sedlar GR, Brown SA. Adolescent substance use and sexual risk-taking behavior. J Adolesc Health 2001; 28:181-9.

32. Correia D, Pontes A, Cavalcante J, Egito E, Maia E. Adolescents: contraceptive knowledge and use, a Brazilian study. ScientificWorldJournal 2009; 9: 37-45.

33. Parsai M, Voisine S, Marsiglia FF, Kulis S, Nieri T. The protective and risk effects of parents and peers on substance use, attitudes, and behaviors of Mexican and Mexican American female and male adolescents. Youth Soc 2009; 40:353-76

34. Horner P, Grogan-Kaylor A, Delva J, Bares C, Andrade F, Castillo $\mathrm{M}$. The association of family and peer factors with tobacco, alcohol, and marijuana use among Chilean adolescents in neighborhood context. Subst Abuse Rehabil 2011; 2:163-72.

35. Pagare D, Meena G, Singh M, Saha R. Risk factors of substance use among street children from Delhi. Indian Pediatr 2004; 41:221-5.

36. Varga CA. How gender roles influence sexual and reproductive health among South African adolescents. Stud Fam Plann 2003; 34:160-72.

37. Tschann JM, Adler NE, Millstein SG, Gurvey JE, Ellen JM. Relative power between sexual partners and condom use among adolescents. J Adolesc Health 2002; 31:17-25.

38. Teva I, Bermúdez MP, Buela-Casal G. Sexual sensation seeking, social stress, and coping styles as predictors of HIV/STD risk behaviors in adolescents. Youth Soc 2010; 42:255-77.

Submitted on 13/Sep/2012

Final version resubmitted on $03 / \mathrm{Sep} / 2013$

Approved on 14/Oct/2013 